\title{
Vanadium Complexes Are in vitro Inhibitors of Leishmania Secreted Acid Phosphatases
}

\author{
Richard S. Mendez ${ }^{1}$, Benjamin M. Dorsey ${ }^{1}$, Craig C. McLauchlan ${ }^{1}$, Matt Beio ${ }^{1}$, Timothy L. Turner ${ }^{1}$, Victoria H. \\ Nguyen ${ }^{1}$, Alexander $\mathrm{Su}^{1}$, William Beynon ${ }^{1}$, Jon A. Friesen ${ }^{1} \&$ Marjorie A. Jones ${ }^{1}$ \\ ${ }^{1}$ Department of Chemistry, Illinois State University, Normal, IL., USA \\ Correspondence: Marjorie A. Jones, Department of Chemistry, Illinois State University, Normal, IL 61790-4160, \\ USA. Tel: 1-309-438-2366. Fax: 1-309-438-5538. E-mail: majone3@ilstu.edu
}

$\begin{aligned} & \text { Received: September 30, } 2013 \quad \text { Accepted: October 31, } 2013 \quad \text { Online Published: December 16, } 2013 \\ & \text { doi:10.5539/ijc.v6n1p35 }\end{aligned}$ URL: http://dx.doi.org/10.5539/ijc.v6n1p35

\begin{abstract}
Leishmaniasis is a parasitic disease caused by the protozoa Leishmania. These organisms secrete acid phosphatases during their growth cycle as an important part of cell targeting to host macrophage cells thus allowing for a successful infection. Secreted acid phosphatases (SAP) are reported to play a significant role in the survival of Leishmania cells, thus evaluation of these enzymes is of interest. The inhibition of SAP can be the focus of a new drug therapy. We tested for SAP activity from Leishmania tarentolae following the addition of a series of vanadium complexes including decavanadate. Cell cultures at different stages in their growth curve were harvested by centrifugation and supernatant was collected. The SAP activity in the supernatant was assayed with the artificial substrate p-nitrophenylphosphate (pNPP). Incubation with orthovanadate resulted in a decrease in activity of $18 \% \pm 1$ relative to the control, in comparison to decavanadate, which resulted in a $35 \% \pm 4$ decrease in activity. Other vanadium complexes showed smaller inhibitory effects than orthovanadate. Some vanadium complexes appeared to have an effect on reducing cell clumping when compared to control cells. The SAP was partially isolated through anion exchange chromatography and results indicate that SAP isozyme forms are present in the supernatant from cells. Future work is focused on obtaining recombinant enzyme which can be more completely characterized for inhibition by vanadium complexes.
\end{abstract}

Keywords: Leishmania, secreted acid phosphatase, enzyme inhibition, vanadium complexes, orthovanadate, decavanadate

\section{Introduction}

\subsection{Leishmaniasis}

Leishmaniasis is a protozoan disease that is classified as one of the "most neglected diseases $\neg$ " because of its association with poverty stricken populations particularly those in tropic and sub-Saharan regions (Berman, 2003; Center for Disease Control and Prevention, 2013). Parasitic Leishmania spp. are the cause for this disease and a sandfly vector transfers Leishmania when biting humans or other hosts. The promastigote form of the organism is carried by the sandfly, and this form differentiates into the amastigote form in macrophages of the alternate host (Vannier-Santos et al., 2002; Center for Disease Control and Prevention, 2013). A variety of invasion and evasion strategies are used by Leishmania in their successful infection of a variety of hosts (Vannier-Santos et al., 2002). Effects of leishmaniasis can range from permanent scarring to death in the case of visceral leishmaniasis if left untreated.

\subsection{Traditional Treatments}

Traditional treatments for leishmaniasis are limited and involve the use of antimony-containing compounds and other drugs. All such treatments are unsatisfactory because they are toxic, expensive, require multiple treatments, or lose effectiveness due to the parasite's ability to acquire drug resistance after prolonged use (Vannier-Santos et al., 2002; Magill, 2009; Croft, 2011; Duncan et al., 2011). Current treatments also have substantial side effects; these side effects may be related to the similarity of cell biology of protozoan parasites to other eukaryotic cells thus increasing toxicity risks. Owing to the large association of this disease with poverty and rural regions, these treatments may not always be available, and there continues to be many chemotherapy challenges (Berman, 1997; Pathak \& Batra, 2009; Croft \& Buffet, 2011; Harhay et al., 2011). Thus, the study of other viable therapy 
directions is important. Drugs that inhibit secreted parasite enzymes, such as secreted acid phosphatase, could help booster the treatment of this disease.

\subsection{Phosphatases and Leishmania}

In general, phosphatases are a large group of enzymes that catalyze the cleavage of phosphate groups from a wide variety of phosphorylated compounds. These enzymes are generally classified relative to the $\mathrm{pH}$ optima (acid, neutral, or alkaline) or relative to important participating amino acids such as with protein tyrosine phosphatase (Vincent et al., 1992; Gani \& Wilkie, 1997). Phosphatases function in opposition to kinases and phosphorylases, acting as important physiological regulators. Thus phosphatases are involved in a number of important physiological roles. Membrane bound acid phosphatases are reported to inhibit the production of neutrophil oxidative metabolites $\mathrm{O}_{2}{ }^{-}$and $\mathrm{H}_{2} \mathrm{O}_{2}$, suggesting a pathophysiological role for membrane-bound acid phosphatases (Remaley et al., 1985). The secreted acid phosphatases are now well established to be different from the membrane-bound acid phosphatase of Leishmania (Glew et al., 1988). The secreted acid phosphatases are also reported to play a significant role in the survival of Leishmania cells. Lovelace and Gottlieb (1986) reported that acid phosphatase activity was secreted by all major species of Leishmania tested except L. major and $L$. tarentolae. However, others reported that L. major promastigotes release soluble acid phosphatases (Shakarian \& Dwyer, 2000). Ellis et al. (1998) reported that Leishmania amastigotes synthesize secretory acid phosphatases during the infection process. Vannier-Santos et al. (1995) reported that secreted acid phosphatase (EC \#: 3.1.3.2) has an important role in Leishmania infectivity, perhaps by enhancing host-parasite interactions. However, the mechanism is not well established. Work on secreted acid phosphatases (SAP), especially from Leishmania, has been reported since the early 1970s. Isolation, partial characterization and possible biological function of these acid phosphatases has progressed so that these enzymes are now well established to be distinct from the other phosphatases of cells especially in terms of cell cycle, protein molecular weight and degree of glycosylation (Gottlieb \& Dwyer, 1982; Ilg et al., 1991, 1994). The secreted acid phosphatases are also reported to play an important role in infectivity (Shakarian \& Dwyer, 2000), thus studies of this enzyme could allow for new therapeutic directions. Disruption of the SAP could result in an increased host immune response thus killing the invading parasite before it is able to establish itself in vivo. It is well documented that orthovanadate $\left(\mathrm{VO}_{4}{ }^{3-}\right)$ is an effective inhibitor of phosphatases, and in general, a variety of vanadium complexes have been shown to inhibit various phosphatases in vitro (reviewed by Gresser et al., 1987). We have also recently reported the inhibitory effects of decavanadate and other select vanadium complexes on several enzymes, especially those using intermediary metabolites with phosphate groups, and on growth of Leishmania tarentolae in vitro (Turner et al., 2012). The mechanism of inhibition was not fully characterized in our previous work (Turner et al., 2012).

\subsection{Hypothesis}

Owing to the ambiguity in the literature concerning leishmanial secreted acid phosphatase and its potential role in Leishmania infectivity, our approach has been to assess the inhibition of L. tarentolae SAP by selected vanadium complexes that have already been reported to moderately affect $L$. tarentolae in culture (Turner et al., 2012). We hypothesize that evaluation of inhibitory effects using partially purified enzyme will give insight into mechanism of inhibition and open new therapeutic directions.

\section{Method}

\subsection{Cells}

Axenic Leishmania tarentolae promastigote cells (ATCC 30143 cells) were grown, at room temperature, in polystyrene $25 \mathrm{~cm}^{2}$ flasks (Corning) in sterile brain-heart infusion (BHI; Becton, Dickinson and Company) medium prepared as per the ATCC recommended protocol with added hemin $(20 \mu \mathrm{M})$, penicillin and streptomycin $(10,000$ units $/ \mathrm{mL}$ and $10 \mathrm{mg} / \mathrm{mL}$, respectively; Sigma-Aldrich) following the general protocol of Morgenthaler et al. (2008). Although L. tarentolae is not a pathogen for humans, we used this species because the promastigotes are easy to grow in culture and can be used as a model system for the human pathogenic species (Taylor et al., 2010). In some cases, the cultures were initiated with a small number of cells on day 0 and in other cases a larger inoculum of cells were used. For enzyme assays, flasks with BHI medium, without cells, were incubated and used for blanks as indicated below. Cells grown in BHI without added vanadium compounds are considered control cells. Cell viability was assessed using the 3-(4,5-dimethylthiazol-2-yl)-2,5-diphenyltetrazolium bromide (MTT) assay (Mosmann, 1983) and cell shape, motility, and clumping were monitored by light microscopy using a Jenco inverted microscope (model CP-2A1; at 100 or $400 \mathrm{x}$ magnification). Data are reported as mean $\pm \mathrm{SD}$ for $\mathrm{n}=3-4$ replicates with some data presented as direct absorbance values and others reported as percent of control cell response. Analysis of variance (ANOVA) was used to evaluate statistical significance. When the hemin was omitted from the culture medium, 
cell growth was undetectable by MTT response or SAP activity (data not shown) due to the overall limited growth of the cells.

Cells were collected and pooled into $50 \mathrm{~mL}$ conical polypropylene tubes. Tubes were centrifuged at 13,667 xg, $4{ }^{\circ} \mathrm{C}$ for 20 minutes to collect the cell-free supernatants which were assayed directly for secreted acid phosphatase activity or used to partially purify the enzyme using anion exchange chromatography. To directly assay the supernatants for secreted acid phosphatase activity, $450 \mu \mathrm{L}$ aliquots were incubated with $450 \mu \mathrm{L}$ of $0.15 \mathrm{M}$ sodium acetate buffer ( $\mathrm{pH} 4.5$ ), and $100 \mu \mathrm{L}$ of freshly prepared $p$-nitrophenylphosphate ( $p \mathrm{NPP}, 13.5 \mathrm{mM}$ in sodium acetate buffer) in $1.5 \mathrm{~mL}$ polypropylene centrifuge tubes. Samples were incubated for up to 24 hours in the dark at room temperature. Reactions were stopped by addition of $100 \mu \mathrm{L}$ of $10 \mathrm{M} \mathrm{NaOH}$. Blanks, containing BHI medium without cell incubation, were incubated and processed the same way as BHI with cells. Absorbance values at $405 \mathrm{~nm}$ were recorded using a Hewlett Packard UV/Vis spectrophotometer with ChemStation Softward.

\subsection{The Vanadium Complexes}

The vanadium complexes used in this study are $\mathrm{V}(\text { pic })_{3}, \mathrm{VO}(\text { pic })_{2}, \mathrm{NH}_{4} \mathrm{VO}_{2}(\text { pic })_{2}, \mathrm{~V}(\mathrm{imc})_{3}, \mathrm{VO}(\mathrm{imc})_{2}$, $\mathrm{NH}_{4} \mathrm{VO}_{2}(\mathrm{imc})_{2}$, sodium orthovanadate $\left(\mathrm{Na}_{3} \mathrm{VO}_{4}\right)$, and $\left[\mathrm{NH}_{4}\right]_{6}\left[\mathrm{~V}_{10} \mathrm{O}_{28}\right] \cdot 5 \mathrm{H}_{2} \mathrm{O}$ (decavanadate; $\mathrm{V}_{10}$ ). Their structures are shown in Supplemental Figure S1. To evaluate the effects of these vanadium complexes, $100 \mu \mathrm{L}$ of freshly prepared complexes (in $0.15 \mathrm{M}$ sodium acetate buffer, $\mathrm{pH} 4.5$ ) were added to the cell-free supernatants $(450 \mu \mathrm{L})$ with $350 \mu \mathrm{L}$ of the same buffer and incubated 10 minutes before addition of $100 \mu \mathrm{L}$ of the $p$ NPP substrate then incubated for up to 24 hours at room temperature in the dark. The final reaction volume was $1.0 \mathrm{~mL}$ in all enzyme assays. The final vanadium complex concentrations tested ranged from 10 to $200 \mu \mathrm{M}$ as indicated. Blanks consisted of BHI without cells but with added complex incubated under the same conditions. Effects of other treatments, such as dithiothreitol (DTT), potassium-sodium tartrate, or heating, were also evaluated. All assays were done in triplicate.

\subsection{Cells With Vanadium Complexes}

Cells with and without added vanadium complexes were evaluated daily by light microscopy for cell shape, motility, and clumping using a Jenco inverted compound microscope. The number of clumps (of greater than an estimated 10-20 cells) on days 5, 6 and 7 of culture were estimated and reported as percent of control cells.

To evaluate the ability of selected vanadium complexes to affect activity of SAP from cells, cultures in early log phase (day 3) were incubated with decavanadate $\left(\mathrm{V}_{10}\right)$, or $\mathrm{V}(\mathrm{imc})_{3}$ at $20 \mu \mathrm{M}$ or $\mathrm{VO}_{4}{ }^{3-}$ at $200 \mu \mathrm{M}$. Cell viability (MTT assay) was evaluated on days 4 through 7 following the additions. Also, SAP activity in the medium (after removal of cells by centrifugation) was evaluated on culture days 4 through 7 .

\subsection{Ion Exchange Column Chromatography}

The partial isolation of SAP was performed in a $4{ }^{\circ} \mathrm{C}$ cold room, and followed the general procedure for anion exchange chromatography reported by Ilg et al. (1994). Running buffer (20 mM Tris-Cl, $100 \mathrm{mM} \mathrm{NaCl}, \mathrm{pH} 7.5)$ was poured into the $20 \mathrm{~mL}$ packed DE51 (Whatman) anion exchange column to wash the resin. Two columns were prepared, one for the partial isolation of SAP from the cell supernatant and the second used as a BHI medium control. The cell free supernatant sample $(112 \mathrm{~mL})$ was obtained following centrifugation $(13,667 \mathrm{xg}$, $20 \mathrm{~min}, 4^{\circ} \mathrm{C}$ ) of L. tarentolae cultured in Brain Heart Infusion (BHI) harvested on day 13 of culture. BHI (50 $\mathrm{mL}$ ) containing no cells and treated identically to the $L$. tarentolae culture was applied to the second column. Both columns were washed with $20 \mathrm{mM}$ Tris-Cl $100 \mathrm{mM} \mathrm{NaCl} \mathrm{pH} 7.5$ (100 mL total) collected as 3 separate volumes (indicated as wash 1, wash 2, and wash 3), then $20 \mathrm{mM}$ Tris-Cl $500 \mathrm{mM} \mathrm{NaCl} \mathrm{pH} 7.5$ (10 mL) was used as the high salt final elution buffer.

\subsection{Enzyme Assay}

Aliquots $(450 \mu \mathrm{L})$ of each column fraction were mixed with $450 \mu \mathrm{L}$ of $0.15 \mathrm{M}$ sodium acetate buffer $(\mathrm{pH} 4.5)$, and $100 \mu \mathrm{L}$ of freshly prepared $p$ NPP $(13.5 \mathrm{mM}$ in sodium acetate buffer) in $1.5 \mathrm{~mL}$ centrifuge tubes. Samples were incubated for 22 hours in the dark at room temperature. Reactions were stopped by addition of $100 \mu \mathrm{L}$ of $10 \mathrm{M} \mathrm{NaOH}$. For each fraction a blank, consisting of the same volume from the BHI cell medium chromatography fraction, was incubated under the same conditions as for the test fractions. The absorbance at $405 \mathrm{~nm}$ was evaluated spectrophotometrically. From this work, approximately $98 \%$ of the original SAP activity was recovered from the column. Column fractions from the flow-through, wash 1 , and the high salt wash were used to test for effects of vanadium complexes. 


\subsection{Testing Inhibitory Effects of Vanadium Complexes With Secreted Acid Phosphatase}

Vanadium complexes (Supplemental Figure S1) were prepared as previously described (Turner et al., 2012) or used as received (sodium orthovanadate). Aliquots $(450 \mu \mathrm{L})$ of column fractions were assayed in $0.15 \mathrm{M}$ sodium acetate buffer $\mathrm{pH} 4.8(400 \mu \mathrm{L})$ with $13.5 \mathrm{mM} p \mathrm{NPP}(100 \mu \mathrm{L})$ with the addition of a vanadium complex $(50 \mu \mathrm{L}$ of freshly prepared stock solutions to give final concentrations of $20 \mu \mathrm{M} \mathrm{V}_{10}, 200 \mu \mathrm{M} \mathrm{VO}_{4}{ }^{3-}$, or $20 \mu \mathrm{M} \mathrm{V}(\mathrm{imc})_{3}$; $\mathrm{n}=2)$ and were compared to control samples containing no vanadium $(\mathrm{n}=2)$. Blanks for the vanadium containing samples were composed of aliquots $(450 \mu \mathrm{L})$ from the corresponding fraction from the BHI chromatography assayed as above. After 22 hours of incubation, in the dark at room temperature, the reactions were stopped by the addition of $10 \mathrm{M} \mathrm{NaOH}(100 \mu \mathrm{L})$ and the samples were evaluated using spectroscopy, A 405 $\mathrm{nm}$. Data are reported as percent of control activity.

\subsection{Enzyme Storage}

Aliquots of partially purified SAP were placed into separate $15 \mathrm{~mL}$ polypropylene conical tubes then stored under different conditions. The various conditions were $4{ }^{\circ} \mathrm{C}$ with no light, $-20^{\circ} \mathrm{C},-20{ }^{\circ} \mathrm{C}$ with $20 \%$ glycerol, $-80{ }^{\circ} \mathrm{C}$ or $-80{ }^{\circ} \mathrm{C}$ with $20 \%$ glycerol. Once stored for 72 hours, samples were evaluated for enzyme activity relative to freshly obtained enzyme.

\subsection{Enzyme Kinetics}

Freshly partially purified enzyme (from the high salt wash) was used to evaluate the kinetic constants using substrate concentrations from 0.4 to $4.5 \mathrm{mM}$ under initial velocity conditions ( 22 hours). Data are reported as $\mu \mathrm{M}$ product formed as a function of substrate concentration and also transformed using the Lineweaver-Burk linearization method.

\section{Results}

\subsection{Studies With Cell Supernatant}

Using supernatant from cultures of Leishmania from which cells were removed by centrifugation, secreted acid phosphatase (SAP) activity was detected using the artificial substrate $p$ NPP. Figure 1 shows the effect of incubation time on the amount of product (as evaluated at A $405 \mathrm{~nm}$ ). The response is linear up to 24 hours of incubation. Figure 2 shows that Leishmania tarentolae are able to secrete active acid phosphatase into their culture medium and that, as the culture ages (and uses up the nutrients and experiences accumulation of metabolic waste products), more SAP activity is detected. SAP activity was detected in the culture medium even after 20 days (Table 1). The difference in SAP measurable activity between cell cultures on different days of senescence (from day 12 to 20 ) was minimal $\pm 12 \%$ variation (as shown in Table 1 ). By day 9 of culture clumping of cells was evident by light microscopy. Also, cells were observed to have little to no motility after day 10 until the end of the experiment, and by day 14 no detectable MTT response was measured. When aliquots of the 20 day culture were transferred to fresh medium, no apparent live cells were detected indicating that cells were not able to recover. When cultures were started with a larger cell inoculum (more than $10^{6}$ cells), the same general trends were observed although the growth curve was shifted to the left so that the stationary phase of the culture was reached much earlier (data not shown).

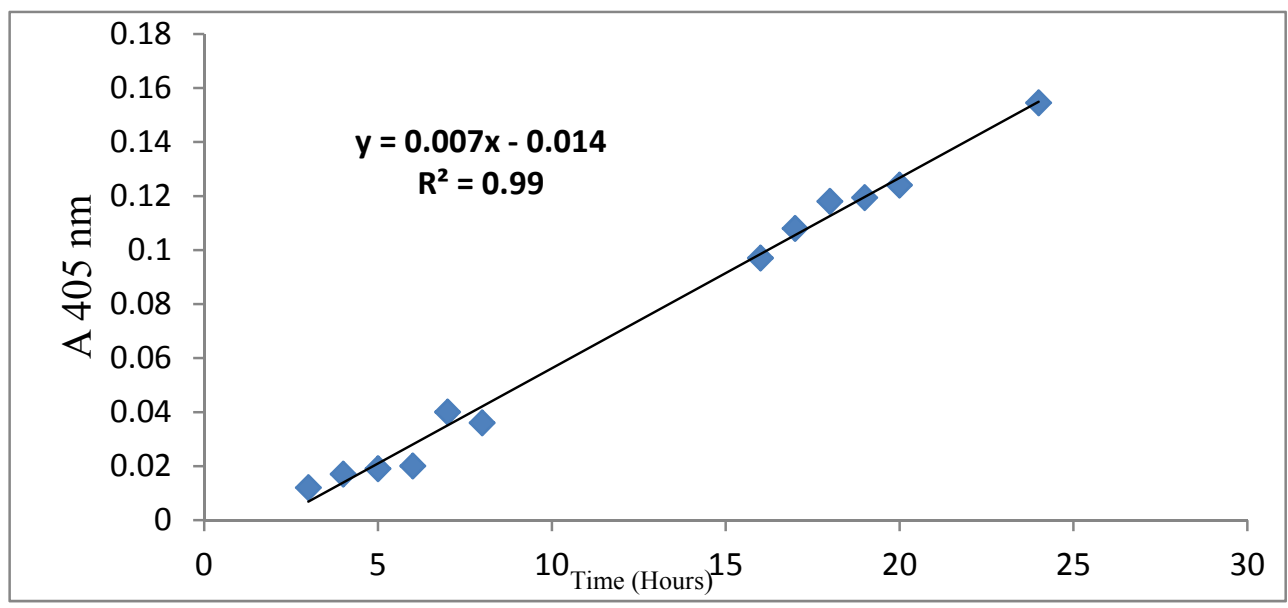

Figure 1. Detection of secreted acid phosphatase (SAP) with time 


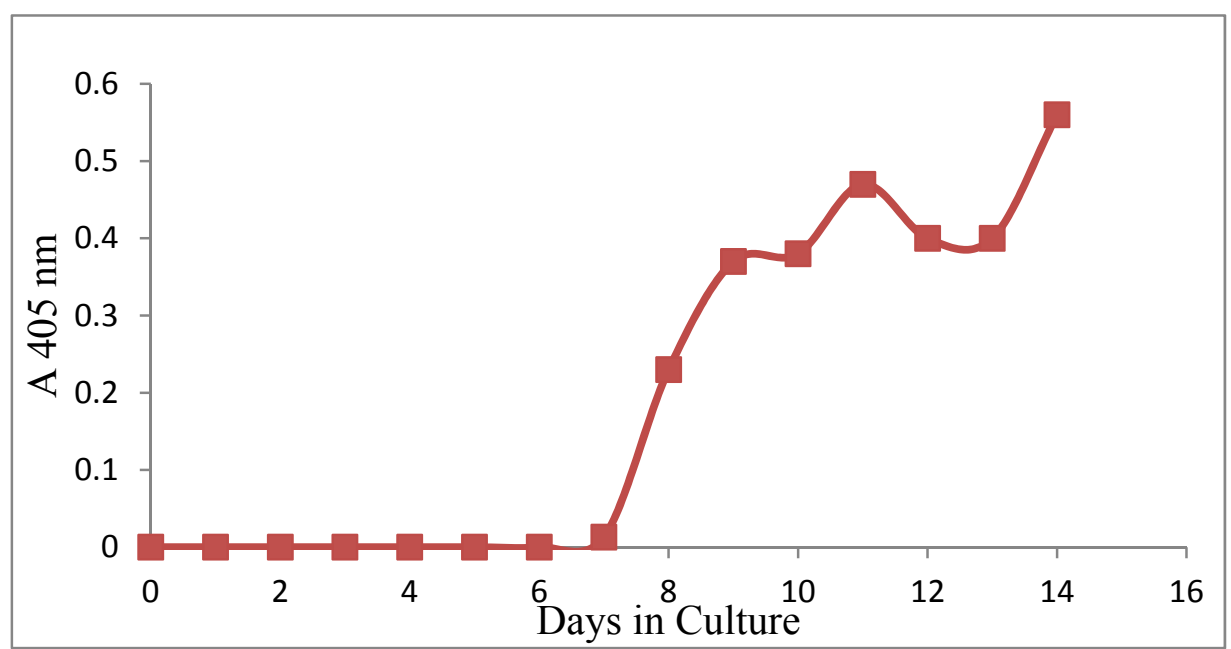

Figure 2. Detection of SAP activity in cell-free medium as a function of days in culture

Table 1 . SAP activity from cultures of 12,15 , and 20 days of age

\begin{tabular}{cc}
\hline Day of Culture & $\begin{array}{c}\text { Units of Activity } \\
(\mu \mathrm{M} / \text { hour })\end{array}$ \\
\hline 12 & 2.25 \\
15 & 2.35 \\
20 & 2.00 \\
\hline
\end{tabular}

\subsection{Enzyme Storage}

Storage of the partially purified SAP for $72 \mathrm{~h}$ showed a change of activity with storage temperature. The enzyme storage conditions that yielded the most active enzyme were either $4{ }^{\circ} \mathrm{C}$ or $-20{ }^{\circ} \mathrm{C}$ (Table 2). The activity of the enzyme at $4{ }^{\circ} \mathrm{C}$ was also evaluated after two weeks of storage and constant activity was determined (data not shown).

Table 2. Effect of storage conditions ( $72 \mathrm{~h})$ on partially purified SAP

\begin{tabular}{lc}
\hline Enzyme Storage & $\begin{array}{c}\text { Units of Activity } \\
(\mu \mathrm{M} / \text { hour })\end{array}$ \\
\hline $4{ }^{\circ} \mathrm{C}$ & 2.29 \\
$4{ }^{\circ} \mathrm{C}$ Dark & 2.09 \\
$-20^{\circ} \mathrm{C}$ & 2.26 \\
$-20{ }^{\circ} \mathrm{C}+20 \%$ Glycerol & 0.77 \\
$-80{ }^{\circ} \mathrm{C}$ & 1.99 \\
$-80{ }^{\circ} \mathrm{C}+20 \%$ Glycerol & 1.25 \\
\hline
\end{tabular}

\subsection{Microscopy}

A typical microscopic field of control promastigote cells on day 5 (at $400 \mathrm{x}$ magnification which allows observation of both individual cells as well as clumps) is shown in Figure 3. 


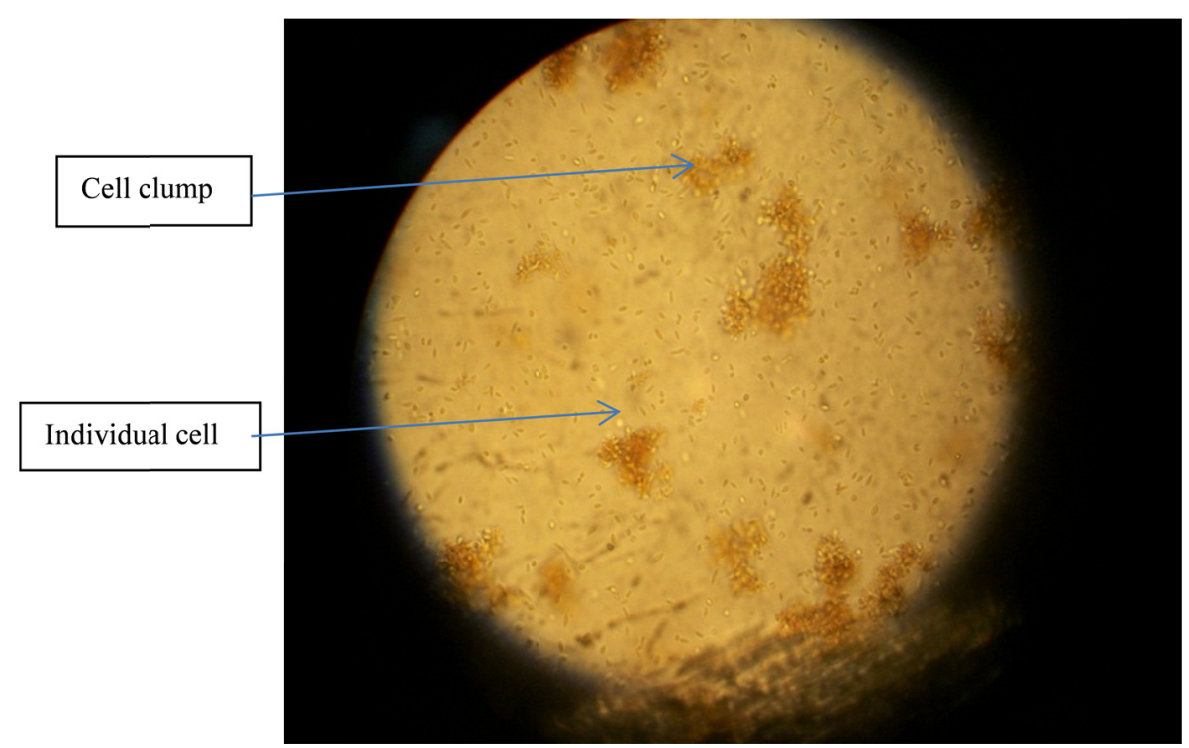

Figure 3. Observation of control Leishmania day 5 culture using the Jenco microscope at $400 \mathrm{x}$ magnification showing typical clumping as well as individual cells

\subsection{Enzyme Stability}

Addition of $10 \mathrm{mM}$ dithiothreitol (DTT) did not affect supernatant SAP activity in the standard assay. However, pre-heating the supernatant at $80{ }^{\circ} \mathrm{C} \pm 10 \mathrm{mM}$ DTT for $10 \mathrm{~min}$ did reduce SAP activity by about $60 \%$. Potassium-sodium tartrate (at levels from 0.06 to $6.0 \mathrm{mM}$ ) did not substantially affect SAP activity in the cell supernatant. Only in the presence of $6 \mathrm{mM}$ tartrate was enzyme activity reduced (to only $38 \%$ of control activity) thus tartrate is only a modest inhibitor of Leishmania tarentolae SAP (data not shown). This low sensitivity to tartrate differs from the report by Gottlieb and Dwyer (1982) who indicated that secreted acid phosphatase activity from $L$. donovani promastigotes was very sensitive to inhibition by $20 \mu \mathrm{M}$ tartrate whereas the membrane-bound activity was 400 times more resistant. We conclude this enzyme from Leishmania tarentolae is quite robust although it does not maintain full activity when frozen with glycerol.

\subsection{Effect of Vanadium Complexes on Secreted Acid Phosphatase}

The vanadium complexes used here have been previously reported (Turner et al., 2012) and are shown in Supplemental Figure S1. Figure 4 shows the effect on secreted acid phosphatase activity from cells (day 6) that had a single addition of one of the vanadium complexes (at a final concentration of $10 \mu \mathrm{M}$ ) added on day 5 . The results of the enzyme assays, as a percent of enzyme activity in the supernatant with no addition, are shown. The picolinate ( pic $^{-}$) complexes all appeared to have no effect on detectable SAP activity under these conditions. Modest inhibition of approximately $10 \%$ by a single dose of the imidazolyl-2-carboxylate (imc') containing complexes $\mathrm{V}(\mathrm{imc})_{3}$, $\mathrm{VO}(\mathrm{imc})_{2}$ or $\mathrm{VO}_{2}(\mathrm{imc})_{2}{ }^{-}$was observed. Addition of 10 or $100 \mu \mathrm{M} \mathrm{VO}_{4}{ }^{3-}$ resulted also in a modest inhibition of approximately $10-18 \%$ whereas addition of decavanadate $\left(\mathrm{V}_{10}\right)$ resulted in about a 35\% inhibition under these experimental conditions. Therefore, decavanadate is the best inhibitor of the compounds tested under these experimental conditions. 


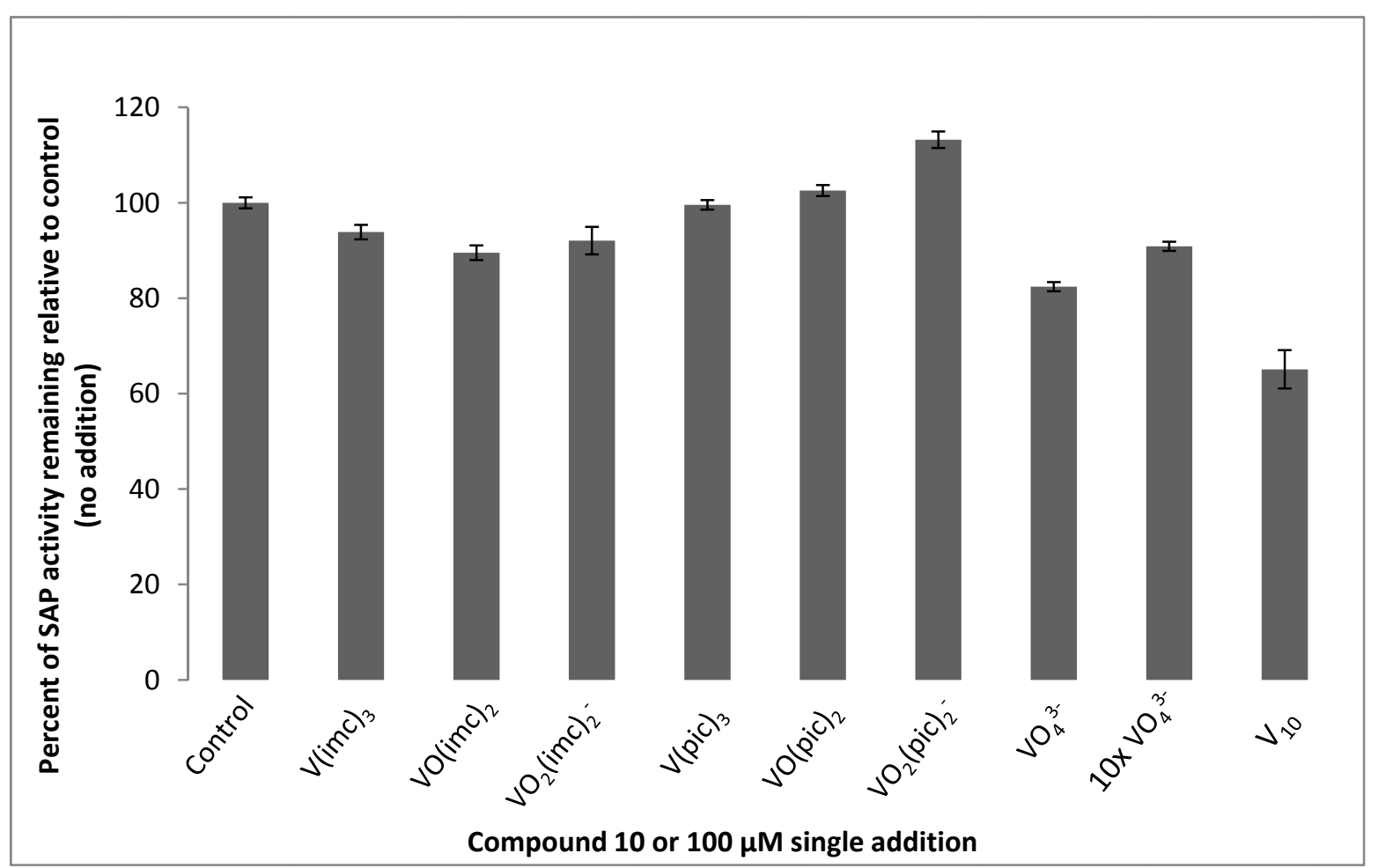

Figure 4. Effect of vanadium complexes (added to cell cultures on day 5) on SAP activity of cell free supernatant assayed 22 hours later. Results are mean \pm SD for $n=4$ replicates

Cells receiving a single $20 \mu \mathrm{M}$ dose of either $\mathrm{V}_{10}$, or $\mathrm{V}(\mathrm{imc})_{3}$ or $200 \mu \mathrm{M} \mathrm{VO}_{4}{ }^{3-}$, on day 3 of culture were evaluated for cell viability (Figure 5) and for secreted acid phosphatase activity (Figure 6). On day 4, the MTT responses from cells with $\mathrm{V}_{10}, \mathrm{VO}_{4}{ }^{3-}$ or $\mathrm{V}(\mathrm{imc})_{3}$ were all significantly decreased (ANOVA, $\mathrm{p}<0.05$ ) relative to the control cells. Of interest is the observation that the largest inhibition was following addition of the $\mathrm{V}(\mathrm{imc})_{3}$. By days 6 and 7 cell responses were not different from that exhibited by control cells and in all cases the cells appear to be in the senescence phase of the growth curve (Figure 5).

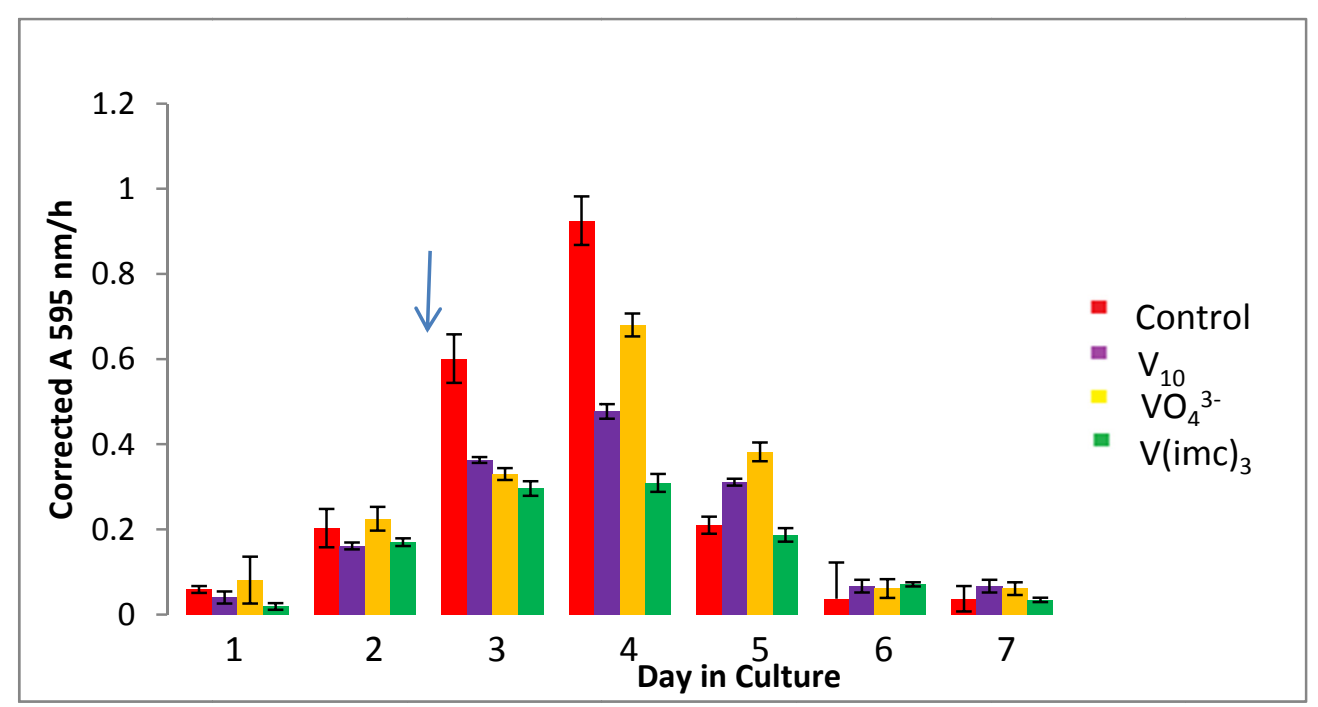

Figure 5. Evaluation of cell viability (using MTT assay) as a function of days in culture; arrow indicates time of addition of indicated final concentration of $20 \mu \mathrm{M}$ vanadium complexes or $200 \mu \mathrm{M}$ for $\mathrm{VO}_{4}{ }^{3-}$. Values are reported as mean $\pm \mathrm{SD}$ for $\mathrm{n}=4$ replicates 
On days 4 and 6, the detectable SAP activity in the supernatant from cells incubated with $\mathrm{V}_{10}, \mathrm{VO}_{4}{ }^{3-}$ or $\mathrm{V}(\mathrm{imc})_{3}$ were all significantly decreased (ANOVA, $\mathrm{p}<0.05$ ) relative to the control cells (Figure 6). However, on day 7 only the SAP activity from cells with $\mathrm{V}_{10}$ or $\mathrm{V}(\mathrm{imc})_{3}$ was significantly decreased (ANOVA, $\mathrm{p}<0.05$ ) relative to the control cells. The cells with the greatest SAP enzymic activity showed more cell clumping. On days 6 and 7 of culture with and without added vanadium complexes, the percent of clumping relative to control cells (Table 3) was determined. In all cases the cells without addition of vanadium complexes had more clumping visible by microscopy. This clumping is normally seen in older cultures and is likely due to reduction of nutrients and accumulation of metabolic waste products. This is of interest because the clumping of cells may have some protective role and be especially important for cells that are stressed. Vanaerschot et al. (2010) evaluated Leishmania donovani for survival capacity and found that stress survival capacity was correlated with infectivity. The cells may be clumping to increase genetic exchange and other adaptive interactions. Thus when considering the reduction in number (and thus percentage) of visible clumps in the cultures with added vanadium complexes, we speculate that the vanadium complexes reduce the normal clumping response to stress. Because $\mathrm{V}_{10}$ is not stable in BHI medium ( $\mathrm{pH}$ 7.2) and has been shown to be substantially degraded in 24 hours (Turner et al., 2012), we speculate that the degradation products also have effects on the Leishmania in culture. More work is needed to identify which intermediate(s) are involved.

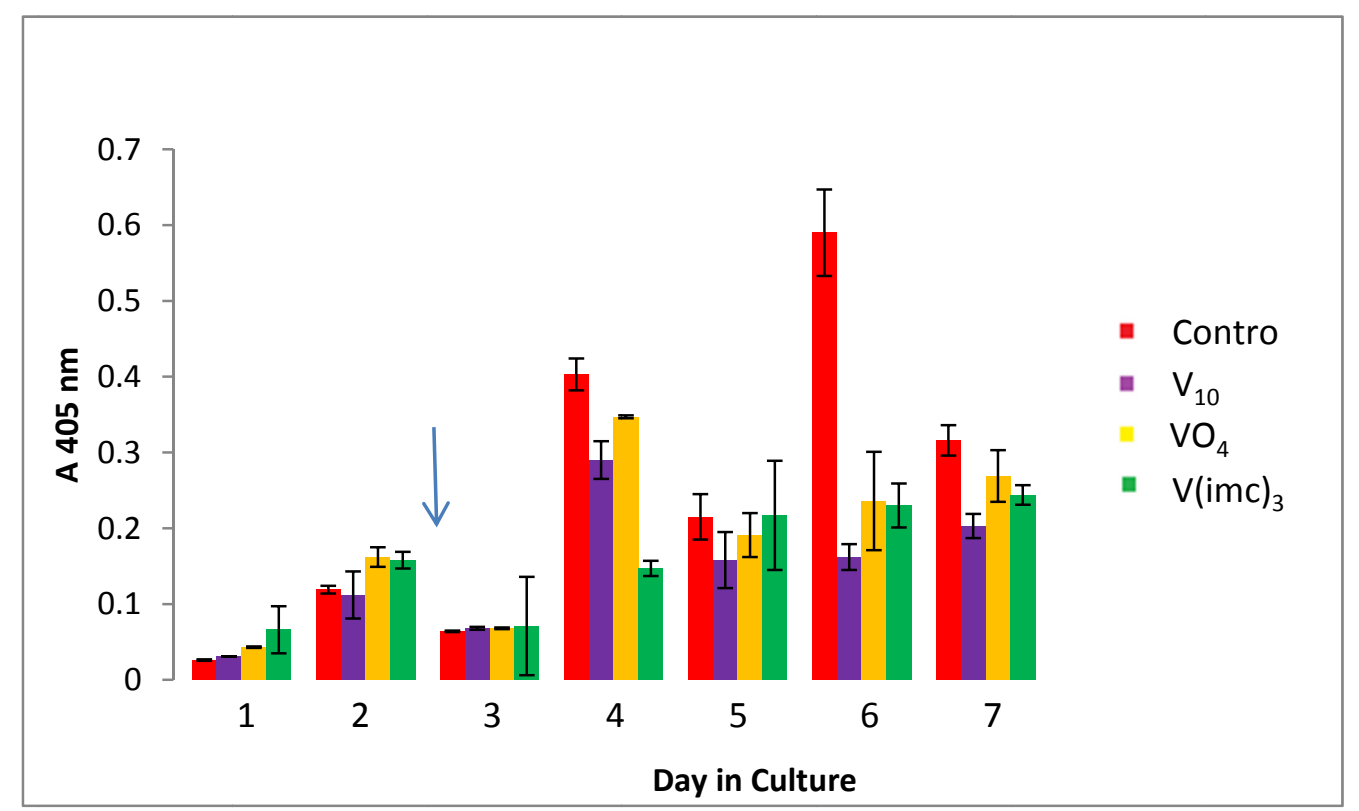

Figure 6. Evaluation of detectable secreted acid phosphatase activity (using $p$ NPP as substrate) as a function of days in culture; arrow indicates time of addition of indicated vanadium complexes at $20 \mu \mathrm{M}$ or $200 \mu \mathrm{M}_{\text {for }} \mathrm{VO}_{4}{ }^{3-}$ final concentrations. Values are reported as mean $\pm \mathrm{SD}$ for $\mathrm{n}=4$ replicates

Table 3. Amount of clumping (monitored at 100 x magnification) after addition (on Day 3) of vanadium complexes relative to control cells

\begin{tabular}{lcc}
\hline \multicolumn{1}{c}{ Additions } & $\begin{array}{c}\text { Day 6 percent clumping } \\
\text { relative to control cells }\end{array}$ & $\begin{array}{c}\text { Day 7 percent clumping } \\
\text { relative to control cells }\end{array}$ \\
\hline No addition (control cells) & 100 & 100 \\
$20 \mu \mathrm{M} \mathrm{V}_{10}$ & $16^{*}$ & $39^{*}$ \\
$200 \mu \mathrm{M} \mathrm{VO}_{4}{ }^{3-}$ & 58 & 91 \\
$20 \mu \mathrm{M} \mathrm{V}(\mathrm{imc})_{3}$ & $48^{*}$ & $39^{*}$ \\
\hline
\end{tabular}

* Indicates significantly different from control cells at $\mathrm{p}<0.05$. 


\subsection{Anion Exchange Chromatography Results}

Approximately $98 \%$ of the original supernatant secreted acid phosphatase activity was recovered from the anion exchange column. The flow-through fraction contained $87 \%$ of the original activity, the first wash, $(20 \mathrm{mM}$ Tris-Cl $100 \mathrm{mM} \mathrm{NaCl}$ ) fraction contained $10.5 \%$, and the second wash contained $0.5 \%$ of the original activity while the third wash contained no detectable enzyme activity. The high salt wash $(20 \mathrm{mM}$ Tris- $\mathrm{Cl} 500 \mathrm{mM} \mathrm{NaCl})$ fraction contained $1.1 \%$ of the activity as shown in Figure 7 . To regenerate the column, it was washed with 150 $\mathrm{mL}$ of running buffer. For spectrophotometric blanks, BHI cell medium (with no cells but incubated under the same conditions) was processed as was the cell-free supernatant and column fractions from a separate anion exchange column were used.
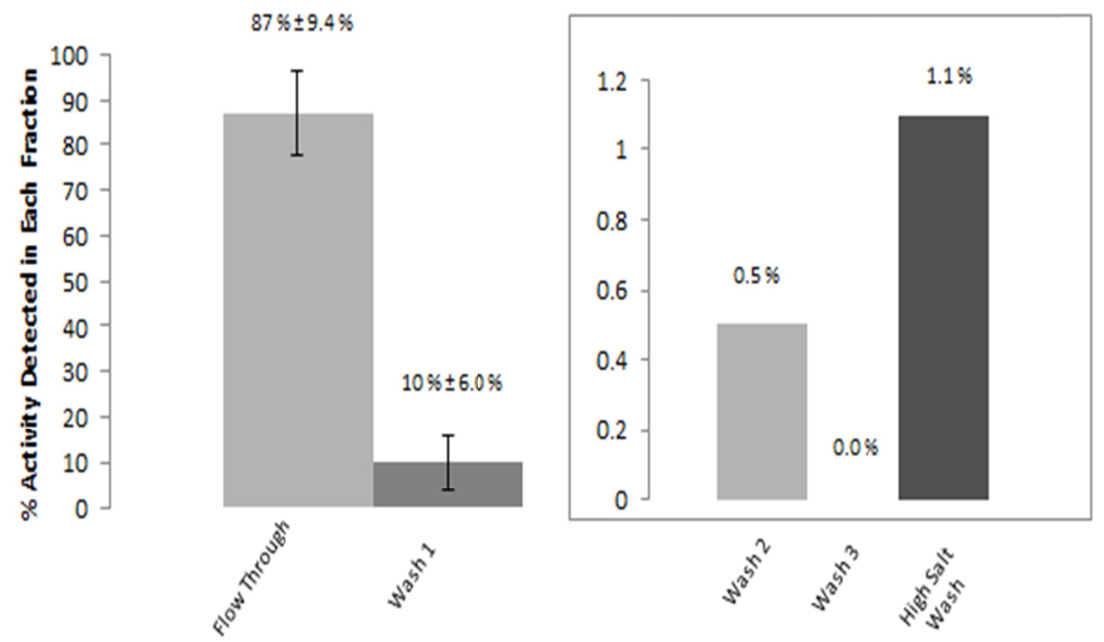

Figure 7. Percent of acid phosphatase from cell-free supernatant detected in each fraction. Values are the mean of 3 measurements with mean \pm SD. Columns without error bars indicate SD values of less than $1 \%$

The three major SAP active fractions collected and assayed following anion exchange chromatography (shown in Figure 7) were incubated with and without addition of $20 \mu \mathrm{M} \mathrm{V}_{10}, \mathrm{~V}(\mathrm{imc})_{3}$, or $\mathrm{VO}_{2}(\mathrm{imc})_{2}{ }^{-}$or $200 \mu \mathrm{M} \mathrm{VO}_{4}{ }^{3-}$ before adding substrate. Washes 2 and 3 were not tested with vanadium complexes. Figures $8 \mathrm{~A}, \mathrm{~B}$, and $\mathrm{C}$ show the data reported as percent of remaining enzyme activity relative to the chromatography fractions with no added complex (control).

As shown, the acid phosphatase activities in the flow through fraction, wash 1 (the first low salt, $100 \mathrm{mM} \mathrm{NaCl}$, wash) and the high salt $(500 \mathrm{mM} \mathrm{NaCl})$ wash were all inhibited by the vanadium complexes tested. However, each fraction exhibited a differential inhibition pattern. In all three fractions, the addition of $\mathrm{V}_{10}$ resulted in the most apparent inhibition under these experimental conditions. The high salt wash was substantially inhibited (95\%) by $\mathrm{V}_{10}$, which is the most sensitive response we have been able to detect. Wash 1 was more inhibited by $\mathrm{V}(\mathrm{imc})_{3}$ than the high salt wash fraction whereas the high salt wash fraction was more inhibited by $\mathrm{VO}_{4}{ }^{3-}$ than the first low salt wash fraction. 

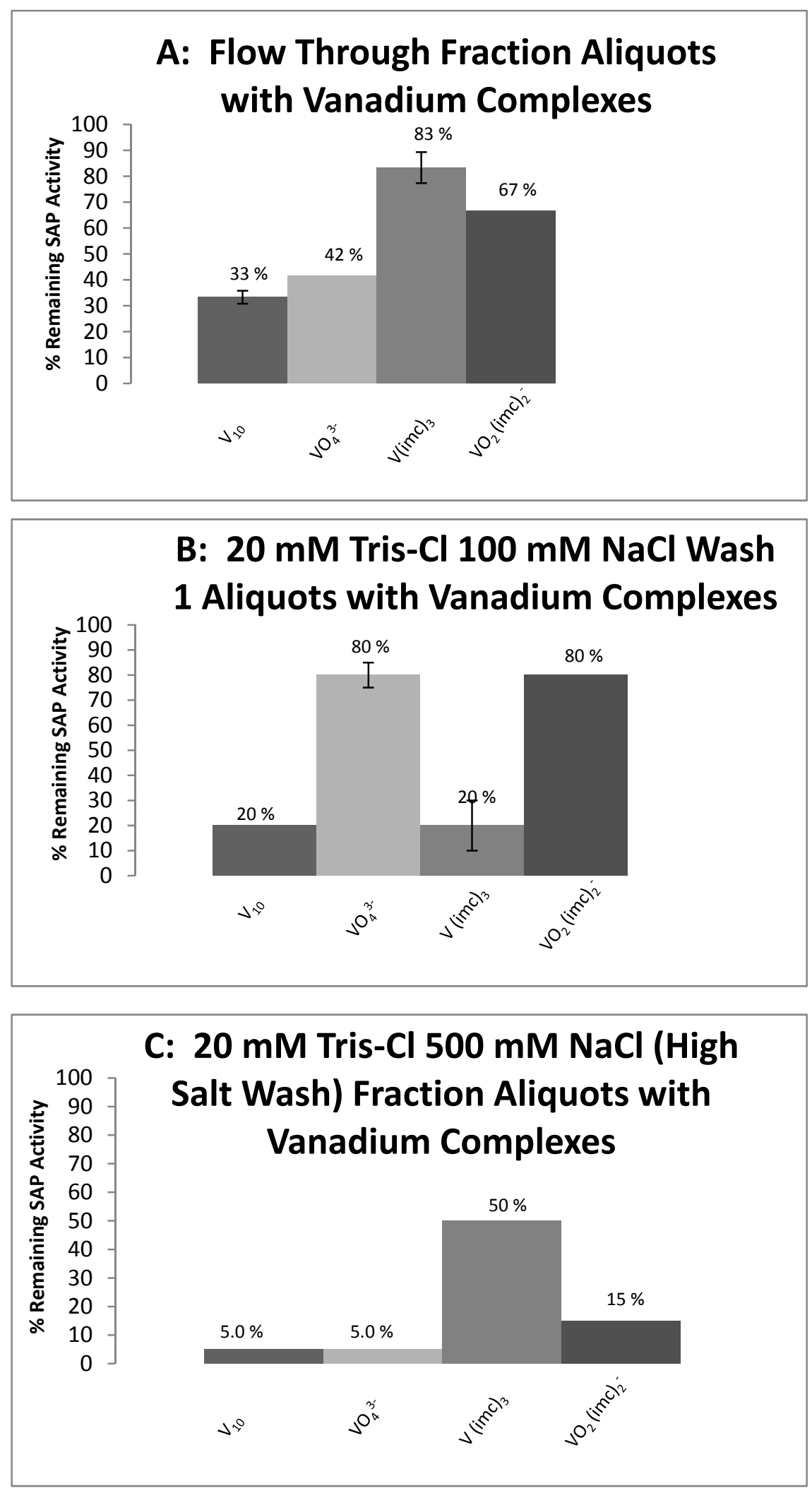

Figure 8. The various fractions collected from the anion exchange column incubated with and without addition of $20 \mu \mathrm{M} \mathrm{V}_{10}, \mathrm{~V}(\mathrm{imc})_{3}$, or $\mathrm{VO}_{2}(\mathrm{imc})_{2}{ }^{-}$or $200 \mu \mathrm{M} \mathrm{VO}_{4}{ }^{3-}$ prior to adding substrate to test for inhibition of SAP activity. Data (mean \pm SD) are reported as percent of remaining SAP activity relative to activity with no added complex. The mean value is indicated above each column. Columns without error bars indicate SD values of less 


\subsection{Enzyme Kinetics}

Enzyme kinetics were investigated with the partially purified SAP (from the high salt wash) that was kept stored at $4{ }^{\circ} \mathrm{C}$. After confirming activity of the enzyme, an enzyme assay was conducted over various substrate concentrations in order to estimate the Michaelis-Menton constants. After plotting units of activity ( $\mu \mathrm{M}$ product formed/22 hour) versus $\mu \mathrm{M} p \mathrm{NPP}$ (Figure 9A), a distinct break was observed in the trend line. When the data were plotted as a Lineweaver-Burk plot two distinct lines were evident (Figure 9B). This suggests that the two different isozymes of SAP are present and that they have different kinetic constants. More studies are needed in order to confirm these results. Tentatively, $\mathrm{K}_{\mathrm{m}}$ values of $1980 \mu \mathrm{M}$ and $230 \mu \mathrm{M}$ and Vmax values of 1.23 $\mu \mathrm{M} /$ hour and $2.98 \mu \mathrm{M} /$ hour, respectively, were extrapolated. These are not dissimilar to the literature reports for $\mathrm{K}_{\mathrm{m}}$ of $740 \mu \mathrm{M}$ (Ilg et al., 1991). It is thus highly likely that the partial isolation procedure results in at least two isozyme forms being present in this fraction. This, of course, makes the kinetics more difficult to interpret. Non-linear Lineweaver-Burk plots can also be the result of non-Michaelis-Menton type enzymes that exhibit cooperativity.
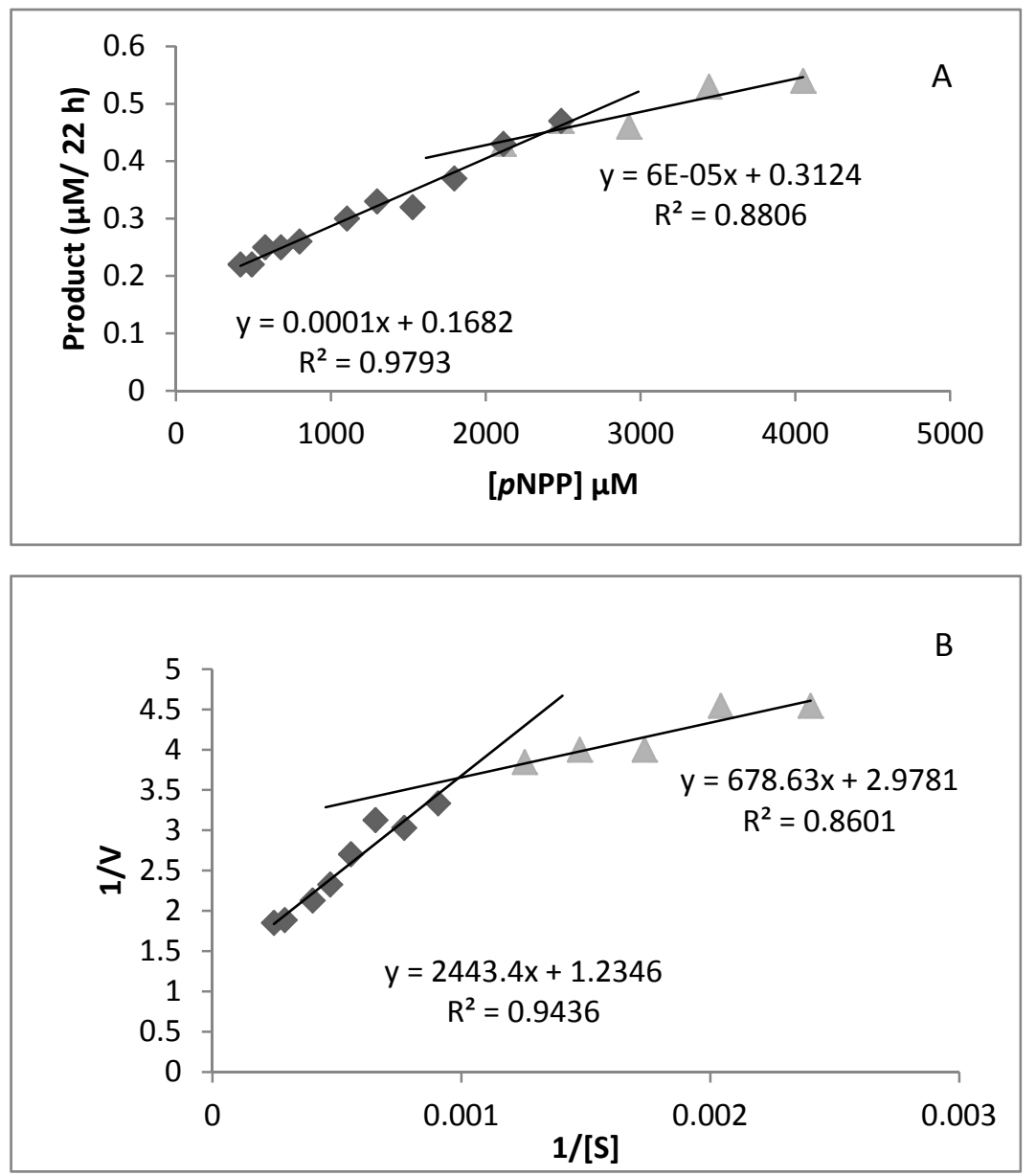

Figure 9. A) Michaelis-Menton plot of product formed under initial velocity conditions as a function of substrate ( $p$ NPP) concentration; B) Lineweaver-Burk Plot

\section{Discussion}

From these studies, we have determined that the secreted acid phosphatase of Leishmania tarentolae is inhibited by vanadium complexes and thus may open up a new direction for treatment of these parasitic diseases. This is of interest especially since the $V_{10}$ compound is relatively easy and inexpensive to synthesize and stable at room temperature as a dry powder (Turner et al., 2012). The potential of vanadium compounds to have a role in the pharmacopeia for a wide variety of problems has been studied for about 100 years with early work involving diabetes, infections, and cancer (reviewed by van de Velde et al., 2000; van Huijsduijnen et al., 2004; Sakurai et 
al., 2004; Aureliano \& Crans, 2009; Olopade \& Conner, 2011) and continuing to parasitic diseases such as leishmaniasis (Turner et al., 2012). That vanadium complexes can affect enzyme activity in vitro as well as in vivo is becoming well established; however the issue of which specific effective species (whether it is the initial vanadium complex or a metabolite) may be much harder to establish. Crans et al. (1990) carefully showed that vanadate tetramer was the inhibiting species when assessing inhibition of 6-phosphogluconate dehydrogenase from human erythrocytes, sheep liver, yeast or Leuconostoc mesenteroides. Because the stability of vanadium complexes is affected by a number of parameters, such as ionic strength, $\mathrm{pH}$, concentration, and temperature as well other variable such as the presence of proteins and other potential ligands, the identity of the specific active species affecting a cell, a transport system, an enzyme, or a receptor remains not well established. In this study, we used a variety of experimental conditions (cell medium, chromatographic buffers, and assay conditions). We have not been able to specifically determine the 'active' component but have shown that addition of $V_{10}$ does affect the activity of the phosphatase measured under specific acidic conditions using a well-established phosphatase substrate. It has long been known that decavanadate is unstable at low concentrations in aqueous solutions (Baes et al., 1976; Csermely et al., 1985; Varga et al., 1985; Chasteen, 1990; Crans et al., 2004). It is also well known that decavanadate solutions decompose at room temperature more quickly in buffer than in water (Csermely et al., 1985; Varga et al., 1985). Despite the fact that decomposition studies predict only mononuclear vanadium $(\mathrm{V})$ as the active form of the inhibitor, there is a clear difference in our studies in the Leishmania SAP activity response to $\mathrm{V}_{10}$ relative to $\mathrm{VO}_{4}{ }^{3-}$ with the same total vanadium concentration implying that different vanadium species are involved. This is in contrast to what has been observed with alkaline phosphatases (Crans et al., 1990, 2004) where similar activity is observed. Such a result is not completely surprising given the lack of stability of $\mathrm{V}_{10}$ at alkaline $\mathrm{pH}$.

Although it is well-known that Leishmania spp. secrete a stable acid phosphatase, understanding of its biological importance is still limited. Despite previous reports that $L$. tarentolae do not secrete acid phosphatase (Lovelace \& Gottlieb, 1986; Glew et al., 1988; Raymond et al., 2012), we find clear evidence that this species does secrete acid phosphatase activity late in culture growth suggesting the secretion may occur as a result of the cells being stressed. Because we are using strain 30143 from ATCC and others report using other strains, perhaps different strains have different abilities. Inhibition of this enzyme, as evidenced here through use of several vanadium complexes, correlated with modest inhibition of Leishmania growth in vitro.

In our hands, as Leishmania tarentolae cell cultures age (enter late stationary phase and progress into senescence), we are able to monitor a marked increase in the ability of cells to join in a clumping activity. Cells in clumps appear able to exhibit motility whereas individual cells in the late stage culture have a reduced ability to be motile. We speculate that this clumping may be an important response to stress since in these culture flasks the nutrients may be limiting and the metabolic wastes from these cells are accumulating. It is tempting to speculate that such clumping will allow the cells to exchange genetic material to help adapt to the stress. If this quorum sensing type behavior is negatively affected by vanadium complexes, this could help reduce the parasite load in a host organism. With even older cultures (more than 20 days), the cells again appear to be as individual cells, highly rounded, and non-motile. Cells from these cultures, when transferred to fresh media, do not appear to recover.

In this study we were able to detect non-cell associated acid phosphatase activity (as defined by the $\mathrm{pH}$ of the enzyme buffer system and use of the well-established phosphatase substrate). It is of great interest to compare the modest inhibition of $\mathrm{V}_{10}$ and the $\mathrm{V}(\mathrm{imc})_{3}$ complexes as well as the $\mathrm{VO}_{4}{ }^{3-}$ using whole cells in culture (Turner, et al., 2012) with the more extensive inhibition measured here using unfractionated cell-free supernatant from senescent cells in addition to the anion exchange chromatography fractions with acid phosphatase activity. The SAP activity of the various column fractions exhibited more sensitivity to the vanadium complexes than the unfractioned supernatant with the high salt eluted fraction having the most apparent inhibition. These differential sensitivity data clearly indicate that there are at least two different acid phosphatase isozymes (SAP 1 and SAP 2, as reported by Ilg et al., 1991, 1994) and possibly more since each column fraction was affected differently in the presence of the vanadium compounds.

The percent SAP enzyme activity recovered from the anion exchange column was about $98 \%$ of initial activity. The anion exchange column was successful for the partial isolation of at least two and perhaps three isozyme forms of SAP as indicated by the greater activity measured in the high salt elution fraction (1.1\%) compared to the activity measured in wash $3(0.0 \%)$ indicating selectivity by the column. The SAP isolated from the flow through fraction was most strongly inhibited by $\mathrm{V}_{10}(67 \%$ inhibition) relative to the other compounds tested. The SAP found in the first wash fraction was most strongly inhibited by $\mathrm{V}_{10}(80 \%)$ or $\mathrm{V}(\mathrm{imc})_{3}(\sim 80 \%)$. The $20 \mathrm{mM}$ Tris-Cl $500 \mathrm{mM} \mathrm{NaCl}$ (high salt wash fraction) showed both $\mathrm{V}_{10}$ and $\mathrm{VO}_{4}{ }^{3-}$ inhibited acid phosphatase activity 
the most $(95 \%)$, followed by $\mathrm{V}(\mathrm{imc})_{3}(50 \%)$ and $\mathrm{VO}_{2}(\mathrm{imc})_{2}{ }^{-}(85 \%)$. The different inhibition profiles between fractions suggest at least two and perhaps three different SAP isozymes exist in Leishmania tarentolae. Because the secreted acid phosphatases are glycoproteins, changes in the degree of glycosylation may have important effects on this inhibition.

Cloning, separation, and study of these individual SAP enzymes is now an important future step towards elucidating their importance in regards to infectivity and general Leishmania life cycle. This current study provides evidence that further studies for therapeutic treatment of leishmaniasis should focus on inhibition of the SAP enzymes. Specifically, a focus on the SAP interaction with host macrophage cells and utilizing vanadium complexes to interfere with infection of the macrophage should be addressed. Currently, we have begun work involving expression of recombinant SAPs which will allow for evaluating the effects of glycosylation of enzyme activity and vanadium complex inhibition studies.

\section{Acknowledgments}

The authors thank the National Science Foundation (US) (CHE0645081) for financial support. Presented in part at the 8th International Vanadium Symposium: Chemistry, Biological Chemistry, \& Toxicology, Washington, DC August 2012.

\section{References}

Aureliano, M., \& Crans, D. C. (2009). Decavanadate $\left(\mathrm{V}_{10} \mathrm{O}_{28}{ }^{6-}\right)$ and oxovanadates: Oxometalates with many biological activities. J. Inorg. Biochem, 103(4), 536-546. http://dx.doi.org/10.1016/j.jinorgbio.2008.11.010

Baes, J., Charles, F., \& Mesmer, R. E. (1976). The First Transition Series. Vanadium. In The Hydrolysis of Cations (pp. 193-210.). New York: John Wiley \& Sons.

Berman, J. D. (1997). Human Leishmaniasis: Clinical, Diagnostic, and Chemotherapeutic Developments in the Last 10 Years. Clinical Infectious Diseases, 24(4), 684-703. http://dx.doi.org/10.1093/clind/24.4.684

Berman, J. D. (2003). Current treatment approaches to leishmaniasis. Curr. Op. Infect. Dis., 16(5), 397-401. http://dx.doi.org/10.1097/00001432-200310000-00005

Center for Disease Control and Prevention - Leishmaniasis. [Internet]. [updated 2010 November 2]. Center for Disease Control. (25 June 2013). Retrieved From http://www.cdc.gov/parasites/leishmaniasis

Chasteen, N. D. (Ed.) (1990). In Vanadium in Biological Systems. Dordrecht, The Netherlands: Kluwer.

Crans, D. C., Smee, J. J., Gaidamauskas, E., \& Yang, L. (2004). The Chemistry and Biochemistry of Vanadium and the Biological Activities Exerted by Vanadium Compounds. Chem. Rev., 104(2), 849-902. http://dx.doi.org/10.1021/cr020607t

Crans, D. C., Willging, E. M., \& Butler, S. R. (1990). Vanadate tetramer as the inhibiting species in enzyme reactions in vitro and in vivo. J. Am. Chem. Soc., 112(1), 427-432. http://dx.doi.org/10.1021/ja00157a063

Croft, S. L., \& Buffet, P. A. (2011). Leishmaniasis. In L. Goldman, \& D. Ausiello (eds.), Cecil Medicine. 24th ed. Philadelphia. Pa: Saunders: Elsevier.

Croft, S. L., \& Olliaro, P. (2011). Leishmaniasis chemotherapy-challenges and opportunities. Clin. Microbiol Infect, 17(10), 1478-1483. http://dx.doi.org/10.1111/j.1469-0691.2011.03630.x

Csermely, P., Martonosi, A., Levy, G. C., \& Ejchart, A. J. (1985). ${ }^{51}$ V-n.m.r. analysis of the binding of vanadium(V) oligoanions to sarcoplasmic reticulum. Biochem J., 230(3), 807-815.

Duncan, R., Gannavaram, S., Dey, R., Debrabant, A., Lakhal-Naouar, I., \& Nakhasi, H. L. (2011). Identification and characterization of genes involved in Leishmania pathogenesis: the potential for drug target selection. Molecu. Biol. Internat., Article ID 428486, 10 pages. http://dx.doi.org/10.4061/2011/428486

Ellis, S. L., Shakarian, A. M., \& Dwyer, D. M. (1998). Leishmania:Amastigotes Synthesize Conserved Secretory Acid Phosphatases during Human Infection. Exp. Parasitol, 89, 161-168. http://dx.doi.org/10.1006/expr.1998.4298

Gani, D., \& Wilkie, J. (1997). Metal ions in the mechanism of enzyme-catalysed phosphate monoester hydrolyses. In Hill HAO, P. J. Sadler, \& A. J. Thomson (Eds.), Metal Sites in Proteins and Models, Structure and Bonding, 89, 133-175. Berlin Heidelberg: Springer. http://dx.doi.org/10.1007/3-540-62874-6_11

Glew, R. H., Saha, A. K., Das, S., \& Remaley, A. T. (1988). Biochemistry of the Leishmania species. Microbiol Reviews, 52(4), 412-432. 
Gottlieb, M., \& Dwyer, D. W. (1982). Identification and partial characterization of an extracellular acid phosphatase activity of Leishmania donovani promastigotes. Mol. Cell Biol., 2(1), 76-81.

Gresser, M. J., Tracy, A. S., \& Stankiewicz, P. J. (1987). The interaction of vanadate with tyrosine kinases and phosphatases. Advances in Protein Phosphatases, 4, 35-37.

Harhay, M. O., Olliaro, P. L., Vaillant, M., Chappuis, F., Lima, M. A., Ritmeijer, K., Costa, C. H., Cosat, D. L., Rijall, S., Sundar, S., \& Balasegaram, M. (2011). Who Is a Typical Patient with Visceral Leishmaniasis? Characterizing the Demographic and Nutritional Profile of Patients in Brazil, East Africa, and South Asia. Am. J. Trop Med. Hyg., 84(4), 543-550. http://dx.doi.org/10.4269/ajtmh.2011.10-0321

Hooft van Huijsduijnen, R., Sauer, W. H. B., Bombrun, A., \& Swinnen, D. (2004). Prospects for Inhibitors of Protein Tyrosine Phosphatase 1B as Antidiabetic Drugs. J. Med. Chem., 47(17), 4142-4146. http://dx.doi.org/10.1021/jm030629n

Ilg, T., Overath, P., Ferguson, M. A. J., Rutherford, T., Campbell, D. G., \& McConville, M. J. (1994). O- and $\mathrm{N}$-glycosylation of the Leishmania mexicana-secreted acid phosphatase. Characterization of a new class of phosphoserine-linked glycans. J. Biol. Chem., 39(269), 24073-24081.

Ilg, T., Stierhof, Y. D., Etges, R., Adrian, M., Harbecke, D., \& Overath, P. (1991). Secreted acid phosphatase of Leishmania mexicana: a filamentous phosphoglycoprotein polymer. Proc. Natl. Acad. Sci. USA, 88, 8774-8778.

Lovelace, J. K., \& Gottlieb, M. (1986). Comparison of extracellular acid phosphatases from various isolates of Leishmania. Am. J. Trop Med. Hyg, 35(6), 1121-1128.

Magill, A. J.(2009). Leishmania species In G. L. Mandell, J. E. Bennett, \& R. Dolin (Eds.), Principles and Practice of Infectious Diseases (7th ed.). Philadelphia, Pa: Elsevier Churchill Livingstone.

McLauchlan, C. C., Hooker, J. D., Jones, M. A., Dymon, Z., Backhus, E. A., Greiner, B. A., ... Manus, L. M. (2010). Inhibition of acid, alkaline, and tyrosine (PTP1B) phosphatases by novel vanadium complexes. $J$. Inorg. Biochem., 104, 274-281. http://dx.doi.org/10.1016/j.jinorgbio.2009.12.001

Morgenthaler, J. B., Peters, S. J., Cedeno, D. L., Constantino, M. H., Edwards, K. A., Kamowski, E. M., ... Jones, M. A. (2008). Carbaporphyrin ketals as potential agents for a new photodynamic therapy treatment of leishmaniasis. Bioorg. Med. Chem., 16(14), 7033-7038. http://dx.doi.org/10.1016/j.bmc.2008.05.037

Mosmann, T. (1983). Rapid colorimetric assay for cellular growth and survival: Application to proliferation and cytotoxicity assays. J. Immunol. Methods., 65(1-2), 55-63. http://dx.doi.org/10.1016/0022-1759(83)90303-4

Olopade, O. J., \& Conner, J. R. (2011). Vanadium and neurotoxicity: A review. Current Topics in Toxicology, 7 , 33-39.

Pathak, R., \& Batra, S. (2009). Malaria and Leishmaniasis: Current Status of Chemotherapy, New Leads and Targets for Drug Discovery. Anti-Infective Agents in Medicinal Chemistry, 8, 226-267. http://dx.doi.org/10.2174/187152109788680216

Raymond, F., Boisvert, S., Roy, G., Ritt, J. F., Legare, D., Isnard, A., ... Corbeil, J. (2012). Genome sequencing of the lizard parasite Leishmania tarentolae reveals loss of genes associated to the intracellular stage of human pathogenic species. Nucleic Acid Res, 40(3), 1131-1147. http://dx.doi.org/10.1093/nar/gkr834

Remaley, A. T., Glew, R. H., Kuhns, D. B., Basford, R. E., Waggoner, A. S., Ernst, L. A., \& Pope, M. (1985). Leishmania donovani: surface membrane acid phosphatase blocks neutrophil oxidative metabolite production. Exp. Parasit, 60(3), 331-341. http://dx.doi.org/10.1016/0014-4894(85)90039-6

Sakurai, H., Fugono, J., \& Yasui, H. (2004). Pharmacokinetic Study and Trial for Preparation of Enteric-Coated Capsule Containing Insulinomimetic Vanadyl Compounds: Implications for Clinical Use. Mini-Rev. Med. Chem., 4(1), 41-48. http://dx.doi.org/10.2174/1389557043487574

Shakarian, A. M., \& Dwyer, D. M. (2000). Structurally conserved soluble acid phosphatases are synthesized and released by Leishmania major promastigotes. Exp. Parasitol, 95(2), 79-84. http://dx.doi.org/10.1006/expr.2000.4511

Taylor, V. M., Muñoz, D. L., Cedeño, D. L., Vélez, I. D., Jones, M. A., \& Robledo, S. M. (2010). Leishmania tarentolae: Utility as an in vitro model for screening of antileishmanial agents. Exp. Parasitol, 126(4), 471-475. http://dx.doi.org/10.1016/j.exppara.2010.05.016

Turner, T. L., Nguyen, V. H., McLauchlan, C. C., Dymon, Z., Dorsey, B. M., Hooker, J. D., \& Jones, M. A. 
(2012). Inhibitory Effects of Decavanadate on Several Enzymes and Leishmania tarentolae In Vitro. J. Inorg. Biochem., 108(3), 96-104. http://dx.doi.org/10.1016/j.jinorgbio.2011.09.009

Van de Velde, F., Arends, I. W. C. E., \& Sheldon, R. A. (2000). Biocatalytic an d biomimetic oxidations with vanadium. J. Inorg. Biochem., 80(1-2), 81-89. http://dx.doi.org/10.1016/S0162-0134(00)00043-X

Vanaerschot, M., Maes, I., Quakad, M., Adaui, V., Maes, L., DeDoncher, S., ... Decuypere, S. (2010). Linking in vitro and in vivo survival of clinical Leishmania donovani strains. PLOS One, 5(8), e12211. http://dx.doi.org/10.1371/journal.pone.0012211

Vannier-Santos, M. A., Martiny, A., \& de Souza, W. (2002). Cell Biology of Leishmanis spp.: Invading and evading. Curr. Pharm. Des., 8(4), 297-318. http://dx.doi.org/10.2174/1381612023396230

Vannier-Santos, M. A., Martiny, A., Meyer-Fernandes, J. R., \& de Souza, W. (1995). Leishmanial protein kinase C modulates host cell infection via secreted acid phosphatase. Eur. J. Cell Biol., 67(2), 112-119.

Varga, S., Csermely, P., \& Martonosi, A. (1985). The binding of vanadium (V) oligoanions to sarcoplasmic reticulum. Eur. J. Biochem., 148(1), 119-126. http://dx.doi.org/10.1111/j.1432-1033.1985.tb08815.x

Vincent, J. B., Crowder, M. W., \& Averill, B. A. (1992). Hydrolysis of phosphate monoesters: a biological problem with multiple chemical solutions. Trends Biochem. Sci., 17(3), $105-110$. http://dx.doi.org/10.1016/0968-0004(92)90246-6

\section{Copyrights}

Copyright for this article is retained by the author(s), with first publication rights granted to the journal.

This is an open-access article distributed under the terms and conditions of the Creative Commons Attribution license (http://creativecommons.org/licenses/by/3.0/). 